\title{
Post-harvest assessment of fruit quality and shelf life of two elite tomato varieties cultivated in Bangladesh
}

\author{
Shata Rupa Sinha', Ashutus Singha ${ }^{2 *}$ (D), Muhiuddin Faruquee ${ }^{3}$, Md. Abu Sayem Jiku², Md. Arifur Rahaman², \\ Md. Ashraful Alam ${ }^{4}$ and Mohammad Abdul Kader ${ }^{5}$
}

\begin{abstract}
Background: Tomatoes are now one of the most popular nutrient-dense vegetables in terms of acreage, production, yield, commercial use, and consumption that add to the Bangladesh economy and ultimately reduce poverty. With this view, a lab investigation was carried out to analyze the effects of tomato (Sofol and Roma VF) verities on different post-harvest managements to extend shelf life as well as reduce post-harvest losses.

Results: This study confirmed that the fruit quality attributes (color, firmness, weight loss, chilling injury, total soluble solids, pH, disease incidence, disease severity, and dry matter content) were increased whereas moisture content, vitamin C, and titratable acidity decreased with the increases in storage duration. The high quality attributes such as color, firmness, weight loss, chilling injury, total soluble solids, $\mathrm{pH}$, disease incidence, disease severity, and dry matter content increased, whereas moisture content, vitamin C and titratable acidity decrease of tomato were observed in Roma VF while Sofol variety had high weight loss, moisture content, titratable acidity, and vitamin C. Moreover, the highest shelf life (17 days) was recorded in Sofol than Roma VF (15 days). On the 16th day of storage, maximum disease severity (41\%) and disease incidence (71\%) were observed at an earthen cooling pot, whereas a significant reduction in disease severity (1\%) and disease incidence (8\%) were recorded in tomatoes stored at $10^{\circ} \mathrm{C}$ temperature. Weight loss was the lowest (4\%) in Sofol when kept at unperforated low-density polyethylene (LDPL) plastic bag as compared to Roma VF treatment (11\%). Considering the physiological process, held at the low temperature $\left(10^{\circ} \mathrm{C}\right.$ and $\left.15^{\circ} \mathrm{C}\right)$ and increased shelf life as well as reduced the diseases of tomatoes.

Conclusions: The investigator concluded that the findings of this study will be helpful with specific regard to long and medium-term storage, quality control, transportation, and advertising, and will also be beneficial to tomato growers of Bangladesh.
\end{abstract}

Keywords: Post-harvest, Physiological processes, Diseases, Tomato (Lycopersicon esculentum L.)

\section{Introduction}

One of the most important vegetables in terms of acreage, production, yield, commercial use, and consumption is the tomato (Solanum Lycopersicun). After potato and sweet potato, it is the most consumable vegetable crop holding the top of the canned vegetable list (Chowdhury 1979). Currently, It is cultivated all over the country including Bangladesh due to its adaptability to a wide

\footnotetext{
* Correspondence: ashutus.iwm@sau.ac.bd

${ }^{2}$ Institute of Environmental and Sustainable development in Agriculture,

Chinese Academy of Agricultural Science, Beijing 100081, China

Full list of author information is available at the end of the article
}

range of soil and climate (Ahmed 1976), Hassan et al. 2010; Kalloo and Sachdev 1985). According to BBS (2012), the annual production of tomato is about 255 thousand metric tons from 23.82 thousand hectares of land with an average yield of 10.71 metric tons/ha. However, tomato is highly perishable because of its climacteric pattern of respiration (Wills et al. 2004). The fruits perishability is attributed to the increases in physiological and physico-chemical changes, such as loss of weight, respiration, transpiration, softening of pulp, sugar, and acid contents (Firmin 1997). In the peak harvesting period of tomato in Bangladesh, sub-standard 
post-harvest operations such as lack of proper storage, inadequate transportation and marketing, and insufficient processing and preservation facilities resulted in a glut in the market, and therefore, the growers fail to avail expected return of produce. Consequently, large volumes of harvested tomatoes are sold at throw-away prices and improper microbial decay also greatly contributes to the high post-harvest loss (Arah et al. 2015).

Maintenance of tomato's quality during marketing is one of the major problems when the fruit is stored at ambient temperature. Pathogen attack is an important problem in the spoilage of tomato in storage. Many fungi and bacteria cause diseases in tomato fruits and result in enormous losses of quantity and quality of the fruits (Patel and Patel 1991). So, it is very important to reduce post-harvest losses of tomato along the supply chain.

The estimated post-harvest loss of tomatoes in the supply chain of Bangladesh is 30\% (Hassan et al. 2010). Earlier reports suggested that post-harvest losses of tomatoes ranged from 20 to $30 \%$ (Coursey 1971) and 30 to 50\% (Lashley 1984). Apart from the above, the quantitative and qualitative (nutritional) losses also occur if suitable post-harvest treatments are not applied. Hence, there is an urgent need to reduce the enormous postharvest loss of tomatoes. Therefore, the lab experiment was undertaken with the following objectives: (i) to investigate the effects of varieties on the shelf life and post-harvest quality attributes of tomatoes in Bangladesh and (ii) to determine the effects of heat treatment, modified atmosphere packaging, and low storage temperatures on shelf life, physico-chemical changes, and microbial infection of tomatoes during storage.

\section{Materials and methods}

\section{Experimental site and atmospheric conditions of storage} room

The experiment was carried out at the Department of Horticulture, Bangladesh Agricultural University, Mymensingh-2202, Bangladesh. The temperatures and relative humidity $(\mathrm{RH})$ ranges for the storage room and earthern cooling pot were $28.2^{\circ} \mathrm{C}$ to $31.1^{\circ} \mathrm{C}$ and $27.2{ }^{\circ} \mathrm{C}$ to $29.5{ }^{\circ} \mathrm{C}$ and the 51 to $76 \%$ and 57 to $79 \%$, respectively and by using Digital Thermo Hygrometer (THERMO, TFA, Germany). Unperforated $(12 \mathrm{~cm} \times 9 \mathrm{~cm})$ LDPE plastic bags were used for this treatment. Twenty-one fruits of each variety were individually kept in unperforated plastic bags and placed on laboratory table at ambient condition for observation.

\section{Method of studying parameters Moisture content}

Ten grams of tomato pulp was weighed by Triple Beam Balance and taken in a Petri dish from each treatment out of each replication. The Petri dish was placed in an electric oven at $70{ }^{\circ} \mathrm{C}$ for $72 \mathrm{~h}$ until the constant weight attained. It was then cooled and weighed again. The moisture content of tomato pulp was calculated using the following formula:

Moisture content/weight losses were calculated using the following formula:

$$
\text { Moisture Content }=\frac{\mathrm{IW}-\mathrm{FW}}{\mathrm{IW}} \times 100
$$

Where IW is the initial weight of fruits (g) and FW is the final weight of fruits at every weight $(\mathrm{g})$. Also, the dry matter percent of the tomato pulp is estimated from the data obtained during moisture estimation using the following formula:

Percent dry matter $=(100-$ percent moisture content $)$

\section{Color and firmness, chilling injury, and disease incidence changes of fruit}

The changes in the color of tomato were determined using a numerical rating scale of $1-7$, where $1=$ green, 2 = breaker, 3 = turning, $4=$ pink, $5=$ light red, $6=$ red, 7 = ripe red (Wills et al. 2004). The firmness of tomato fruit was determined by hand feel using a numerical rating scale of $1-6$, where $1=$ hard, $2=$ sprung, $3=$ between sprung and eating ripe, $4=$ eating ripe, $5=$ overripe, and $6=$ rotten. The chilling injury of the fruits during storage was qualitatively determined based on visual observation using a numerical rating scale of 1-4 $(1=$ no chilling injury, $2=$ slight chilling injury, $3=$ moderate chilling injury, $4=$ severe chilling injury). The disease incidence was calculated (Zhang et al. 2014) as follows:

Disease incidence $(\%)=$

(number of infected fruits/total number of fruits at every date $) \times 100$

\section{Vitamin C content}

The vitamin $C$ content of the sample was calculated by using the following formula (Ali et al. 2015)

$$
\begin{aligned}
& \text { Vitamin } C \text { content }(\mathrm{mg} / 100 \mathrm{mg}) \\
& \left.=\left(\left(\mathrm{Ts} \times \mathrm{D} \times \mathrm{V}_{1}\right) / \mathrm{V}_{2} \times \mathrm{W}\right) \times 100\right)
\end{aligned}
$$

Where $T=$ titre, $D=$ dye factor, $V_{1}=$ volume made up, $V_{2}=$ volume of extract, $W=$ weight of sample. The dye factor was calculated using this formula: dye factor $=(0.5 /$ titre $)$. 


\section{TSS and titratable acidity}

Total soluble solids (TSS) content of tomato pulp was estimated using Abbe's refractometer. A drop of tomato juice squeezed from the fruit pulp was placed on the prism of the refractometer and TSS was recorded as \%Brix from a direct reading of the instrument. Temperature corrections were made using the temperature correction chart. Titratable acidity of tomato pulp was determined according to the method mentioned by Ranganna (1979).

\section{$\mathrm{pH}$}

pH 7 and pH 4 buffer tablet (BDH) chemicals Ltd. Poole, England) was dissolved in water and made up to the mark of $100 \mathrm{ml}$ with distilled water. For the determination of pulp $\mathrm{pH}, 4 \mathrm{gm}$ of fresh pulp was taken in a conical flask containing $10 \mathrm{ml}$ of distilled water. Then, the pulp was crushed thoroughly in a mortar and pestle and extract was filtered through two of cloths. The $\mathrm{pH}$ meter (Hannan) was calibrated by using the buffer solutions of $\mathrm{pH} 7$ and $\mathrm{pH} 4$ when correction for temperature was also taken into consideration. On completion of calibration, the electrode was washed twice with distilled water, rinsed with tomato juice, and dipped into the juice and the $\mathrm{pH}$ was recorded.

\section{Plant materials}

In this study, the freshly harvested tomato named "Sofol" and "Roma VF" varieties which were planted as winter tomato. The tomato fruits were collected from the local farmer of village Koltapara under Gouripur Upazila of Mymensingh on 28 April 2015. Tomatoes were kept in perforated low-density polyethylene (LDPE) bags (Fig. 1) for observation. A brief description of tomato varieties is given in Table 1.

\section{Treatments and experimental design}

The tomato variety $V_{1}=$ "Roma VF" and $V_{2}=$ "Sofol" and each variety of eight treatments were considered and the experiment was constructed with the factorial arrangement in a complete block design with three replications presented in Table 2.

\section{Post-harvest data collection}

To assess the effect of varieties and post-harvest treatments on the quality and shelf life of tomatoes during storage period, the fruits of the experiment had been keenly observed and recorded at every 2 days on the abovementioned parameters. In this present study, different characters such as physical (color, firmness, total weight loss, moisture content and dry matter content, and chilling injury), chemical (total soluble solids (TSS), $\mathrm{pH}$, titratable acidity (TA) and vitamin $\mathrm{C}$ content, microbial (disease incidence, disease severity, and postharvest disease-causing organisms) characters, and shelf life of tomatoes was calculated as affected by different storage treatments.

\section{Isolation and identification of causal pathogens}

For identification of causal pathogens, a clean slide was selected and a drop of cotton blue was placed on the slide. Specimen was collected by scraping with sterilized scalpel, blade and was placed on the cotton blue. A cover slip was placed on the specimen. The surrounding area of cover slip was cleaned with soft cloth. Then the prepared slides were observed under compound microscope for identifying the pathogenic structures. After 24 $\mathrm{h}$ the prepared slides were made permanent by using nail polish and taken to the plant disease clinic of the Department of Plant Pathology, BAU to take photographic image of the organisms.
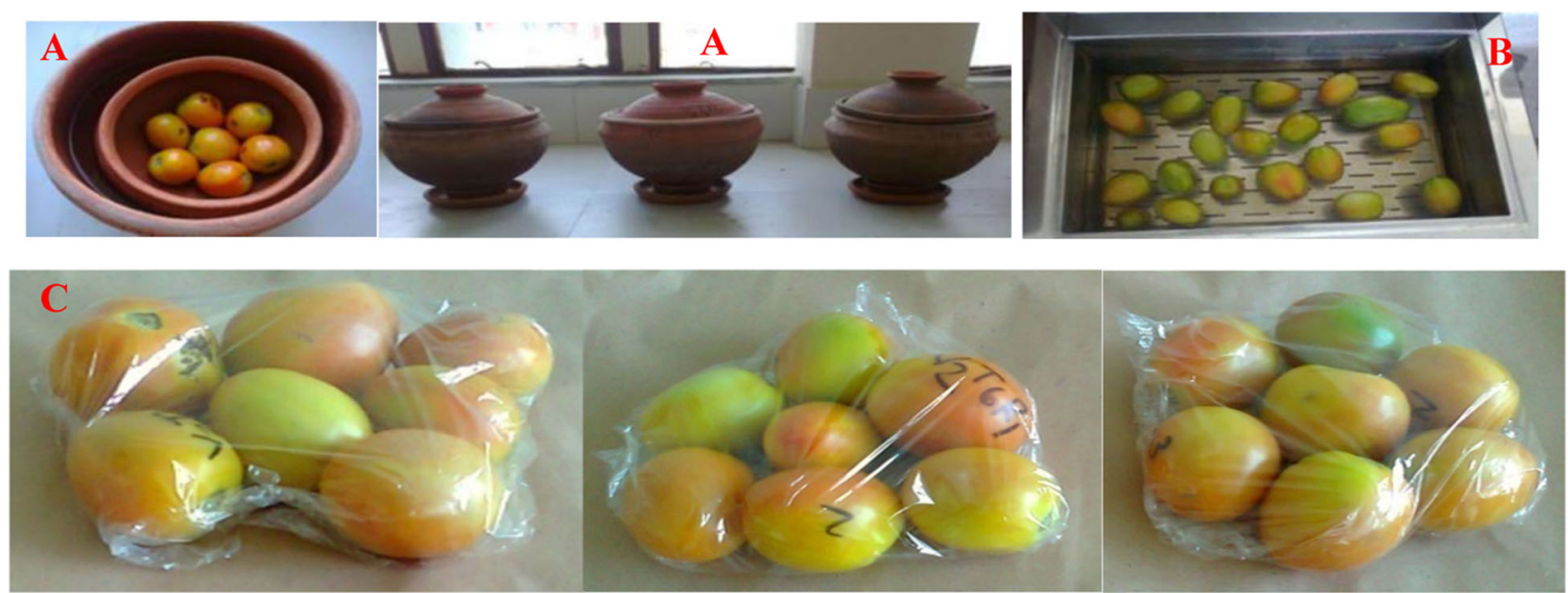

Fig. 1 Ambient condition observation. a Storage of tomato fruit in earthen cooling pot $\mathbf{b}$ at water bath for hot water treatment $\mathbf{c}$ wrapped with LDPE bags 
Table 1 Basic information about two tomato varieties in Bangladesh

\begin{tabular}{lll}
\hline Characters & Roma VF & Sofol \\
\hline General & Fruits are oblong or pear-shaped & Fruit oblate, medium size \\
& Medium firm with a uniform green shoulder & Medium firm and uniform fruit size with excellent shelf life \\
& Fruit weight 85 to $100 \mathrm{~g}$ & Fruit weight $90-100 \mathrm{~g}$ \\
Others & Tolerance to Verticillium wilt, Fusarium wilt race, and Alternaria. & Good for long-distance transportation \\
Company & Lal Teer Seed Company, Bangladesh & Syngenta Company Limited, Bangladesh \\
\hline
\end{tabular}

\section{Shelf life}

Shelf life of tomato fruits as influenced by different postharvest treatments was calculated by counting the days required to ripe fully with retained optimum marketing and eating qualities.

\section{Statistical analysis}

The collected data on various parameters were statistically analyzed using MSTAT Statistical Package. The means for all the treatments were calculated and analysis of variances (ANOVA) for all the parameters were performed by $F$ test. The significance of difference between the pair of means was compared by least significant difference (LSD) test at the $1 \%$ and $5 \%$ levels of probability (Gomez and Gomez 1984).

\section{Results}

\section{Color, firmness, and total weight loss}

Significant variation was found in respect of color changes of two tomato varieties during storage periods. Higher color score (5.91) was observed in Roma VF than that of Sofol (5.23) at 16th day of storage shown in Fig. 2a. The rates of changes in color were faster in treatment combinations of Roma VF with Control, Roma VF with 15 ${ }^{\circ} \mathrm{C}$ temperature and Roma VF with Hot water, and the rate was the slowest in the treatment combination Sofol with unperforated LDPE plastic bags (Table 3).

Statistically highly significant variation was observed in respect to the firmness of tomato between two varieties during storage. The higher rate of firmness score (4.52) was found in Roma VF and the lower in Sofol (4.20) at the 16th day of storage presented in Fig. 2b. Post-harvest treatments exerted a significant effect on the firmness of tomatoes during storage and ripening. The maximum change in firmness (5.20) was observed in Roma VF with control treatment and minimum change in firmness (2.91) in Sofol with unperforated LDPE packaging at the 16th day of storage (Table 4). However, the variation in percent weight loss was highly significant due to the effects of variety at all the day of storage. Sofol lost more weight than Roma VF at the 4th, 6th, 8th, 10th, 12th, and 14th day, respectively; presented in Fig. 2c. The findings indicated that Roma VF was superior to Sofol in respect of reduced weight loss (Table 5).

\section{Moisture and dry matter content}

The variation was observed between the varieties in respect to moisture content. The variety Sofol had higher moisture content $(89.43 \%)$ at the 12th day of storage than Roma VF (87.3\%). The combination effects of variety and post-harvest treatments in respect of moisture content was found statistically highly significant at all days of storage. The highest moisture content (92.67\%) was observed in Sofol with unperforated LDPE bags and the lowest was $(84.62 \%)$ in Roma VF with control treatment combination at 4 th and 12 th DAS respectively (Table 6).

\section{Chilling injury and total soluble solids}

In the present study, the chilling injury was examined under 10 and $15{ }^{\circ} \mathrm{C}$ storage. The main effects of variety were non-significant in the early part of 4 days storage

Table 2 Different treatments following in experiment

\begin{tabular}{ll}
\hline Treatment & Condition \\
\hline $\mathrm{T}_{1}$ & Control (room temperature) \\
$\mathrm{T}_{2}$ & $10^{\circ} \mathrm{C}$ (tomato stored at $10^{\circ} \mathrm{C}$ temperature) \\
$\mathrm{T}_{3}$ & $15^{\circ} \mathrm{C}$ (tomato stored at $15^{\circ} \mathrm{C}$ temperature) \\
$\mathrm{T}_{4}$ & Hot water treatment (tomatoes treated with hot water at $55 \pm 1{ }^{\circ} \mathrm{C}$ for 4 min and kept in ambient condition) \\
$\mathrm{T}_{5}$ & Earthen cooling pot (tomatoes kept in an earthen cooling pot) \\
$\mathrm{T}_{6}$ & Plastic film (tomatoes wrapped with food-grade ultra-thin plastic film) \\
$\mathrm{T}_{7}$ & Unperforated LDPE bags (tomatoes sealed in unperforated LDPE bag) \\
$\mathrm{T}_{8}$ & Perforated LDPE bags (tomatoes sealed in perforated LDPE bag) \\
\hline
\end{tabular}




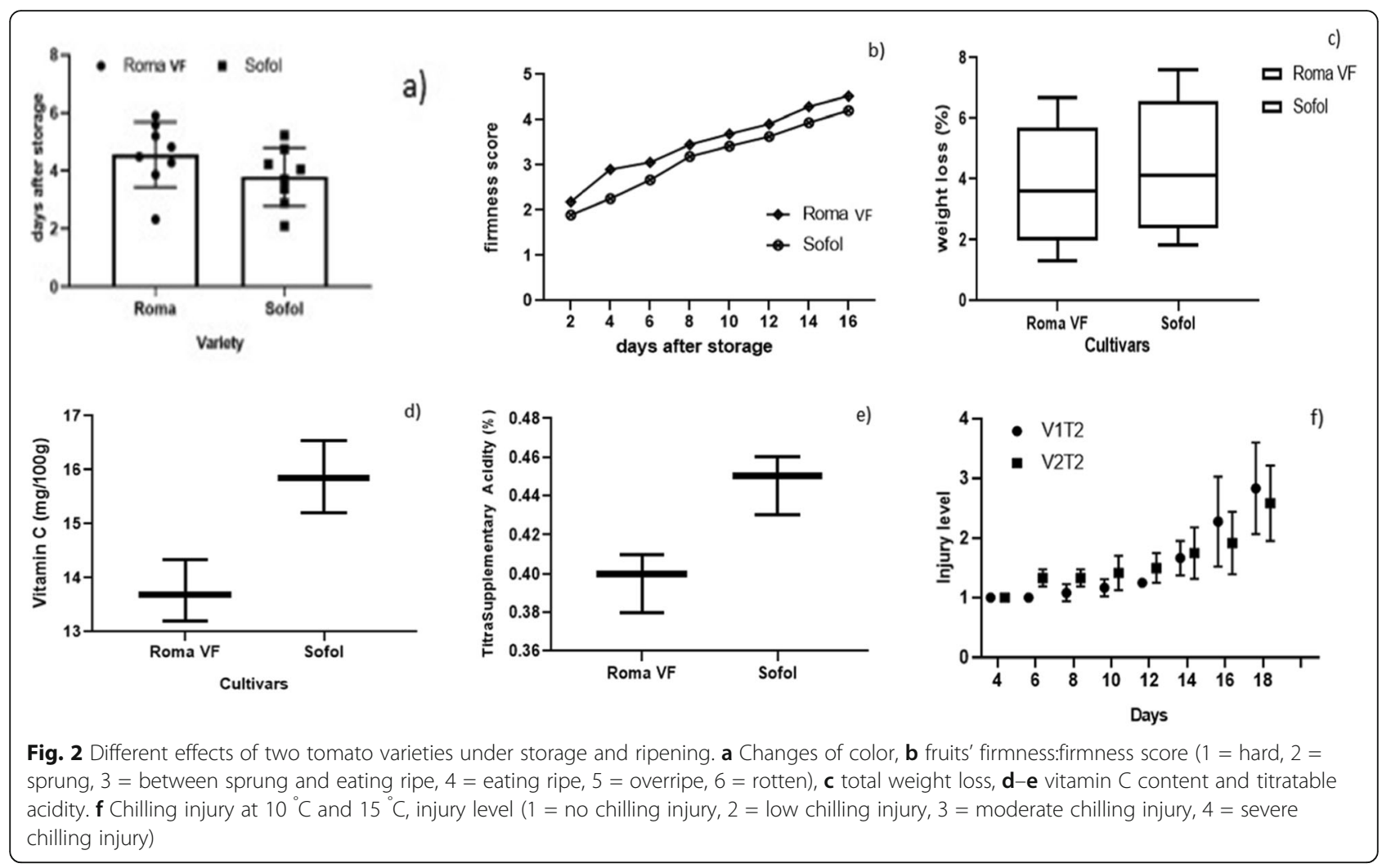

Table 3 Combined effect of varieties and postharvest treatments on changes of color of tomato fruits during storage and ripening

\begin{tabular}{|c|c|c|c|c|c|c|c|c|}
\hline \multirow{2}{*}{$\begin{array}{l}\text { Treatment } \\
\text { combination }\end{array}$} & \multicolumn{8}{|c|}{ Colour(a) at different days after storage } \\
\hline & 2 & 4 & 6 & 8 & 10 & 12 & 14 & 16 \\
\hline$V_{1} T_{1}$ & 2.91 & 4.16 & 4.75 & 4.91 & 5.33 & 5.83 & 6.08 & 6.58 \\
\hline$V_{1} T_{2}$ & 2.16 & 3.66 & 3.75 & 3.83 & 4.17 & 4.91 & 5.16 & 5.25 \\
\hline$V_{1} T_{3}$ & 2.58 & 4.16 & 4.66 & 4.75 & 5.33 & 5.58 & 6.08 & 6.33 \\
\hline$V_{1} T_{4}$ & 2.33 & 4.08 & 4.58 & 4.75 & 5.16 & 5.50 & 5.92 & 6.33 \\
\hline $\mathrm{V}_{1} T_{5}$ & 2.17 & 3.75 & 4.25 & 4.67 & 4.83 & 5.33 & 5.75 & 6.16 \\
\hline$V_{1} T_{6}$ & 2.17 & 3.75 & 4.08 & 4.50 & 4.75 & 5.00 & 5.67 & 6.16 \\
\hline$V_{1} T_{7}$ & 2.08 & 3.33 & 3.66 & 3.75 & 4.00 & 4.08 & 4.16 & 4.33 \\
\hline$V_{1} T_{8}$ & 2.25 & 4.08 & 4.50 & 4.75 & 5.08 & 5.41 & 5.83 & 6.17 \\
\hline $\mathrm{V}_{2} \mathrm{~T}_{1}$ & 2.43 & 3.67 & 3.92 & 4.00 & 4.25 & 4.42 & 5.58 & 5.67 \\
\hline$V_{2} T_{2}$ & 1.99 & 2.50 & 3.00 & 3.60 & 3.91 & 4.00 & 4.25 & 4.50 \\
\hline$V_{2} T_{3}$ & 2.30 & 3.27 & 3.80 & 4.00 & 4.20 & 4.40 & 5.50 & 5.63 \\
\hline$V_{2} T_{4}$ & 2.24 & 3.00 & 3.69 & 3.91 & 4.20 & 4.37 & 4.97 & 5.60 \\
\hline $\mathrm{V}_{2} \mathrm{~T}_{5}$ & 2.08 & 2.75 & 3.27 & 3.72 & 4.10 & 4.27 & 4.79 & 5.54 \\
\hline$V_{2} T_{6}$ & 2.00 & 2.66 & 3.21 & 3.67 & 4.08 & 4.17 & 4.25 & 5.33 \\
\hline$V_{2} T_{7}$ & 1.58 & 2.42 & 2.75 & 2.90 & 3.50 & 3.83 & 3.91 & 4.00 \\
\hline$V_{2} T_{8}$ & 2.19 & 2.93 & 3.42 & 3.80 & 4.18 & 4.37 & 4.84 & 5.60 \\
\hline $\mathrm{LSD}_{0.05}$ & 0.158 & 0.263 & 0.129 & 0.139 & 0.210 & 0.229 & 0.197 & 0.182 \\
\hline $\mathrm{LSD}_{0.01}$ & 0.212 & 0.354 & 0.173 & 0.187 & 0.283 & 0.309 & 0.265 & 0.245 \\
\hline Level of significance & $* *$ & ** & * & $* *$ & $* *$ & $* *$ & $* *$ & $* *$ \\
\hline
\end{tabular}

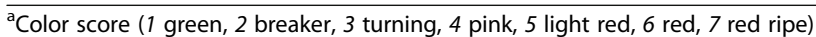

* Significant at $5 \%$ level of probability

**Significant at $1 \%$ level of probability 
Table 4 Combined effect of varieties and postharvest treatments on firmness of tomato during storage and ripening

\begin{tabular}{|c|c|c|c|c|c|c|c|c|}
\hline \multirow{2}{*}{$\begin{array}{l}\text { Treatment } \\
\text { combination }\end{array}$} & \multicolumn{8}{|c|}{ Firmness (b) of tomato at different days after storage } \\
\hline & 2 & 4 & 6 & 8 & 10 & 12 & 14 & 16 \\
\hline$V_{1} T_{1}$ & 2.33 & 3.33 & 3.58 & 3.81 & 4.00 & 4.50 & 4.83 & 5.20 \\
\hline$V_{1} T_{2}$ & 2.10 & 2.67 & 2.87 & 3.33 & 3.58 & 3.83 & 4.00 & 4.33 \\
\hline$V_{1} T_{3}$ & 2.20 & 2.73 & 2.92 & 3.67 & 3.83 & 3.92 & 4.33 & 4.50 \\
\hline$V_{1} T_{4}$ & 2.30 & 3.25 & 3.33 & 3.78 & 3.98 & 4.18 & 4.73 & 4.90 \\
\hline$V_{1} T_{5}$ & 2.25 & 3.15 & 3.30 & 3.76 & 3.85 & 4.12 & 4.41 & 4.70 \\
\hline$V_{1} T_{6}$ & 2.28 & 3.18 & 3.31 & 3.77 & 3.89 & 4.15 & 4.53 & 4.74 \\
\hline$V_{1} T_{7}$ & 1.92 & 2.25 & 2.33 & 2.50 & 3.08 & 3.17 & 3.50 & 3.67 \\
\hline$V_{1} T_{8}$ & 2.08 & 2.67 & 2.83 & 3.00 & 3.33 & 3.42 & 4.00 & 4.08 \\
\hline$V_{2} T_{1}$ & 2.33 & 2.48 & 3.16 & 3.80 & 3.97 & 4.13 & 4.47 & 5.00 \\
\hline$V_{2} T_{2}$ & 1.67 & 2.08 & 2.42 & 2.92 & 3.17 & 3.25 & 3.53 & 3.62 \\
\hline$V_{2} T_{3}$ & 1.87 & 2.25 & 2.50 & 3.08 & 3.50 & 3.58 & 4.08 & 4.47 \\
\hline$V_{2} T_{4}$ & 2.10 & 2.41 & 3.08 & 3.75 & 3.91 & 4.10 & 4.40 & 4.80 \\
\hline$V_{2} T_{5}$ & 1.92 & 2.27 & 2.75 & 3.47 & 3.70 & 4.00 & 4.33 & 4.58 \\
\hline$V_{2} T_{6}$ & 2.00 & 2.37 & 2.97 & 3.53 & 3.89 & 4.07 & 4.38 & 4.67 \\
\hline$V_{2} T_{7}$ & 1.58 & 2.08 & 2.17 & 2.25 & 2.42 & 2.67 & 2.83 & 2.91 \\
\hline $\mathrm{V}_{2} \mathrm{~T}_{8}$ & 1.67 & 2.08 & 2.33 & 2.75 & 2.83 & 3.25 & 3.50 & 3.58 \\
\hline LSD $_{0.05}$ & 0.118 & 0.204 & 0.158 & 0.197 & 0.257 & 0.197 & 0.263 & 0.246 \\
\hline $\mathrm{LSD}_{0.01}$ & 0.158 & 0.274 & 0.212 & 0.265 & 0.347 & 0.265 & 0.354 & 0.332 \\
\hline Level of significance & $* *$ & $* *$ & * & $* *$ & $* *$ & $* *$ & NS & $* *$ \\
\hline
\end{tabular}

Significant $b$ firmness score ( 1 hard, 2 sprung, 3 between sprung and eating ripe, 4 eating ripe, 5 over ripe, 6 rotten), NS not

* Significant at $5 \%$ level of probability

**Significant at $1 \%$ level of probability

and significant at the later part of 14 days storage. Sofol showed slightly better results than Roma VF in this regard. The combined effects of variety and different postharvest treatments on chilling injury levels of tomato were significant in all cases except days 4 and 16 . The highest injury was observed in $V_{1} T_{2}$ (Roma VF with 10 ${ }^{\circ} \mathrm{C}$ temperature) combination (Table 7).

The varietal difference in terms of TSS showed statistically significant at the 4th, 8th, and 12th day of storage. The variety Roma VF had higher TSS content than Sofol throughout the storage period presented in Fig. 2f. The variety Roma VF showed the highest (5.20\%Brix) TSS content than Sofol $(4.35 \%$ Brix $)$ at the 4 th day of storage. The combined effects showed highly significant result in terms of the TSS (Table 8). The combined effects of variety and different post-harvest treatments on chilling injury levels of tomato were significant at all cases except days 4 and 16 . The highest injury was observed in $V_{1} T_{2}$ (Roma VF with $10{ }^{\circ} \mathrm{C}$ temperature) combination.

\section{$\mathrm{pH}$ of fruit juice and titratable acidity}

There was a significant increase of $\mathrm{pH}$ in both varieties of fruits during storage; $\mathrm{pH}$ was increased from 4.33 to 4.44 in Roma VF while in Sofol it was 4.15 to 4.33 at 4 th and 8 th day of storage (Table 8). Titratable acidity was decreased with the advancement of the storage period. Acidity (\%) was always wider in variety Sofol $(0.46,0.45$, and 0.43 ) than Roma VF

Table 5 Effects of varieties on total weight loss of tomato during storage and ripening

\begin{tabular}{|c|c|c|c|c|c|c|}
\hline \multirow[t]{2}{*}{ Variety } & \multicolumn{6}{|c|}{ Total weight loss (\%) of tomato at different days after storage } \\
\hline & 4 & 6 & 8 & 10 & 12 & 14 \\
\hline Roma VF & 1.30 & 2.18 & 2.87 & 4.35 & 5.37 & 6.68 \\
\hline Sofol & 1.83 & 2.58 & 3.36 & 4.92 & 6.23 & 7.60 \\
\hline $\mathrm{LSD}_{0.05}$ & 0.080 & 0.111 & 0.187 & 0.206 & 0.236 & 0.312 \\
\hline $\mathrm{LSD}_{0.01}$ & 0.107 & 0.148 & 0.249 & 0.275 & 0.315 & 0.416 \\
\hline Level of significance & $* *$ & $* *$ & $* *$ & $* *$ & $* *$ & ** \\
\hline
\end{tabular}

**1 \% level of significance 
Table 6 Combined effect of varieties and postharvest treatments on moisture content and dry matter content of tomato during storage and ripening

\begin{tabular}{|c|c|c|c|c|c|c|}
\hline \multirow{2}{*}{$\begin{array}{l}\text { Treatment } \\
\text { combination }\end{array}$} & \multicolumn{3}{|c|}{ Dry matter content (\%) at different DAS } & \multicolumn{3}{|c|}{ Moisture content (\%) at different DAS } \\
\hline & 4 & 8 & 12 & 4 & 8 & 12 \\
\hline$\overline{V_{1} T_{1}}$ & 12.20 & 13.96 & 15.38 & 87.80 & 86.04 & 84.62 \\
\hline$V_{1} T_{2}$ & 12.20 & 13.70 & 15.12 & 87.80 & 86.30 & 84.88 \\
\hline$V_{1} T_{3}$ & 10.93 & 11.93 & 12.92 & 89.07 & 88.07 & 87.08 \\
\hline$V_{1} T_{4}$ & 10.47 & 11.37 & 12.72 & 89.53 & 88.63 & 87.28 \\
\hline$V_{1} T_{5}$ & 9.83 & 10.43 & 11.85 & 90.17 & 89.57 & 88.15 \\
\hline$V_{1} T_{6}$ & 9.73 & 10.18 & 10.71 & 90.27 & 89.82 & 89.29 \\
\hline$V_{1} T_{7}$ & 9.07 & 9.82 & 10.58 & 90.93 & 90.18 & 89.42 \\
\hline$V_{1} T_{8}$ & 10.27 & 11.00 & 12.33 & 89.73 & 89.00 & 87.67 \\
\hline$V_{2} T_{1}$ & 8.90 & 10.88 & 11.80 & 91.10 & 89.12 & 88.20 \\
\hline$V_{2} T_{2}$ & 8.30 & 10.03 & 11.75 & 91.70 & 89.97 & 88.25 \\
\hline$V_{2} T_{3}$ & 8.20 & 10.00 & 11.68 & 91.80 & 90.00 & 88.32 \\
\hline$V_{2} T_{4}$ & 8.13 & 9.96 & 11.68 & 91.87 & 90.04 & 88.32 \\
\hline$V_{2} T_{5}$ & 7.80 & 8.42 & 9.41 & 92.20 & 91.58 & 90.59 \\
\hline$V_{2} T_{6}$ & 7.54 & 8.30 & 9.10 & 92.46 & 91.70 & 90.90 \\
\hline$V_{2} T_{7}$ & 7.33 & 8.20 & 9.00 & 92.67 & 91.80 & 91.00 \\
\hline$V_{2} T_{8}$ & 7.97 & 9.02 & 10.17 & 92.03 & 90.98 & 89.83 \\
\hline LSD $_{0.05}$ & 0.881 & 0.650 & 0.806 & 0.573 & 0.473 & 0.913 \\
\hline $\mathrm{LSD}_{0.01}$ & 1.187 & 0.876 & 1.085 & 0.772 & 0.637 & 1.231 \\
\hline Level of significance & * & $* *$ & $* *$ & $* *$ & $* *$ & $* *$ \\
\hline
\end{tabular}

${ }^{*}$ and ${ }^{* *}$ indicate $5 \%$ and $1 \%$ level of significance. V1: Roma VF, V2: Sofol, T1: Control, T2: Fruits stored at $10^{\circ} \mathrm{C}$ temperature, T3: Fruits stored at $15^{\circ} \mathrm{C}$ temperature, T4: Hot water treatment $\left(55^{\circ} \mathrm{C}\right)$ for $4 \mathrm{~min}$, T5: tomato stored in earthen cooling pot, T6: Fruits stored in food grade plastic film, T7: Fruits stored in unperforated plastic bags, T8: Fruits stored in perforated plastic bags

$(0.41,0.40$, and 0.38$)$ during the entire storage period (Fig. 2e). The interaction effect between variety and postharvest treatments in respect of titratable acidity was not significant during the entire storage period. It was highest $(0.49 \%)$ in Sofol with unperforated LDPE combination at 4th day of storage, while it was the lowest $(0.30 \%)$ in Roma VF with control combination at 12th day of storage followed by Sofol with control (0.35\%) and Roma VF with hot water $(0.37 \%)$ (Table 9).

\section{Vitamin C content}

The ascorbic acid content of fruit pulp varied significantly among the fruits of the two varieties. Sofol and Roma VF contained vitamin $C$ of $16.54 \mathrm{mg} / 100 \mathrm{~g}$ and $14.34 \mathrm{mg} / 100$ $\mathrm{g}$ at the 4th day of storage, respectively, which decreases gradually with the advancement of storage period shown in Fig. 2d. Among the post-harvest treatments used in the study significantly influenced on vitamin $C$ content of fruits during the entire storage period (Table 9).

Table 7 Combined effect of varieties and different postharvest treatments on chilling injury level of tomato during storage and ripening

\begin{tabular}{|c|c|c|c|c|c|c|c|c|}
\hline \multirow{2}{*}{$\begin{array}{l}\text { Treatment } \\
\text { combination }\end{array}$} & \multicolumn{8}{|c|}{ Chilling injury (c) level at different days after storage } \\
\hline & 4 & 6 & 8 & 10 & 12 & 14 & 16 & 18 \\
\hline $\mathrm{V}_{1} \mathrm{~T}_{2}$ & 1.00 & 1.00 & 1.08 & 1.17 & 1.25 & 1.67 & 2.28 & 2.83 \\
\hline$V_{1} T_{3}$ & 1.00 & 1.33 & 1.33 & 1.42 & 1.50 & 1.75 & 1.92 & 2.58 \\
\hline $\mathrm{V}_{2} \mathrm{~T}_{2}$ & 1.08 & 1.33 & 1.58 & 1.50 & 1.58 & 1.67 & 1.92 & 2.00 \\
\hline$V_{2} T_{3}$ & 1.00 & 1.00 & 1.33 & 1.42 & 1.42 & 1.58 & 1.58 & 2.07 \\
\hline $\mathrm{LSD}_{0.05}$ & 0.053 & 0.074 & 0.105 & 0.118 & 0.139 & 0.074 & 0.139 & 0.074 \\
\hline $\mathrm{LSD}_{0.01}$ & 0.071 & 0.100 & 0.142 & 0.158 & 0.187 & 0.100 & 0.187 & 0.100 \\
\hline Level of significance & NS & $* *$ & $* *$ & $* *$ & $* *$ & $* *$ & NS & $* *$ \\
\hline
\end{tabular}

NS not significant, $V 1$ Roma VF, V2 Sofol, $T 2$ fruits stored at $10{ }^{\circ} \mathrm{C}$ temperature, $T 3$ fruits stored at $15^{\circ} \mathrm{C}$ temperature **1 \% level of significance 
Table 8 Combined effects of varieties and postharvest treatments on total soluble solids of tomato during storage and ripening

\begin{tabular}{|c|c|c|c|c|c|c|}
\hline \multirow{2}{*}{$\begin{array}{l}\text { Treatment } \\
\text { combination }\end{array}$} & \multicolumn{3}{|c|}{ Total soluble solids (TSS) at different days after storage } & \multicolumn{3}{|c|}{$\mathrm{pH}$ at different days after storage } \\
\hline & 4 & 8 & 12 & 4 & 8 & 12 \\
\hline$\overline{V_{1} T_{1}}$ & 5.33 & 5.10 & 5.40 & 4.40 & 4.63 & 4.79 \\
\hline$V_{1} T_{2}$ & 4.60 & 5.57 & 4.93 & 4.30 & 4.37 & 4.53 \\
\hline$V_{1} T_{3}$ & 5.10 & 5.00 & 5.13 & 4.25 & 4.44 & 4.56 \\
\hline$V_{1} T_{4}$ & 4.53 & 5.47 & 4.50 & 4.35 & 4.47 & 4.62 \\
\hline$V_{1} T_{5}$ & 5.90 & 5.95 & 4.73 & 4.35 & 4.22 & 4.65 \\
\hline$V_{1} T_{6}$ & 5.13 & 4.37 & 4.67 & 4.38 & 4.45 & 4.83 \\
\hline$V_{1} T_{7}$ & 5.50 & 4.93 & 5.73 & 4.27 & 4.42 & 4.58 \\
\hline$V_{1} T_{8}$ & 5.53 & 4.60 & 4.63 & 4.35 & 4.53 & 4.72 \\
\hline$V_{2} T_{1}$ & 4.50 & 4.47 & 4.66 & 4.21 & 4.41 & 4.56 \\
\hline$V_{2} T_{2}$ & 4.00 & 4.37 & 4.57 & 4.15 & 4.33 & 4.50 \\
\hline$V_{2} T_{3}$ & 4.10 & 4.07 & 4.40 & 4.15 & 4.37 & 4.53 \\
\hline$V_{2} T_{4}$ & 4.53 & 4.20 & 4.33 & 4.15 & 4.28 & 4.48 \\
\hline$V_{2} T_{5}$ & 4.37 & 4.37 & 4.68 & 4.12 & 4.23 & 4.47 \\
\hline$V_{2} T_{6}$ & 4.43 & 4.50 & 4.73 & 4.20 & 4.42 & 4.52 \\
\hline$V_{2} T_{7}$ & 4.40 & 4.86 & 5.12 & 4.08 & 4.25 & 4.40 \\
\hline$V_{2} T_{8}$ & 4.50 & 4.67 & 4.96 & 4.15 & 4.32 & 4.48 \\
\hline $\operatorname{LSD}_{0.05}$ & 0.182 & 0.204 & 0.297 & 0.074 & 0.091 & 0.118 \\
\hline $\operatorname{LSD}_{0.01}$ & 0.245 & 0.274 & 0.401 & 0.100 & 0.123 & 0.158 \\
\hline Level of significance & $* *$ & $* *$ & $* *$ & NS & $* *$ & * \\
\hline
\end{tabular}

Table 9 Combined effect of varieties and different postharvest treatments on vitamin C content and titratable acidity of tomato

\begin{tabular}{|c|c|c|c|c|c|c|}
\hline \multirow{2}{*}{$\begin{array}{l}\text { Treatment } \\
\text { combination }\end{array}$} & \multicolumn{3}{|c|}{ Vitamin C (mg/100g) at different DAS } & \multicolumn{3}{|c|}{ Titratable Acidity (\%) at different DAS } \\
\hline & 4 & 8 & 12 & 4 & 8 & 12 \\
\hline$\overline{V_{1} T_{1}}$ & 12.32 & 11.40 & 10.48 & 0.333 & 0.316 & 0.300 \\
\hline$V_{1} T_{2}$ & 13.00 & 12.80 & 12.00 & 0.433 & 0.420 & 0.400 \\
\hline$V_{1} T_{3}$ & 15.00 & 14.50 & 14.00 & 0.425 & 0.415 & 0.410 \\
\hline$V_{1} T_{4}$ & 12.00 & 11.80 & 11.00 & 0.400 & 0.390 & 0.370 \\
\hline$V_{1} T_{5}$ & 14.58 & 14.02 & 13.65 & 0.435 & 0.431 & 0.400 \\
\hline$V_{1} T_{6}$ & 13.90 & 12.00 & 11.90 & 0.410 & 0.390 & 0.377 \\
\hline$V_{1} T_{7}$ & 17.22 & 17.00 & 16.80 & 0.440 & 0.435 & 0.382 \\
\hline$V_{1} T_{8}$ & 16.70 & 16.10 & 15.80 & 0.430 & 0.420 & 0.401 \\
\hline $\mathrm{V}_{2} \mathrm{~T}_{1}$ & 14.28 & 12.44 & 10.94 & 0.390 & 0.370 & 0.350 \\
\hline$V_{2} T_{2}$ & 15.65 & 15.20 & 15.00 & 0.481 & 0.470 & 0.450 \\
\hline$V_{2} T_{3}$ & 17.95 & 17.80 & 17.35 & 0.469 & 0.458 & 0.453 \\
\hline $\mathrm{V}_{2} \mathrm{~T}_{4}$ & 16.20 & 14.70 & 13.05 & 0.450 & 0.440 & 0.420 \\
\hline $\mathrm{V}_{2} \mathrm{~T}_{5}$ & 16.88 & 16.50 & 15.80 & 0.486 & 0.481 & 0.456 \\
\hline $\mathrm{V}_{2} \mathrm{~T}_{6}$ & 15.88 & 15.15 & 14.70 & 0.430 & 0.418 & 0.412 \\
\hline$V_{2} T_{7}$ & 18.20 & 18.08 & 18.05 & 0.490 & 0.484 & 0.445 \\
\hline$V_{2} T_{8}$ & 17.30 & 16.95 & 16.70 & 0.480 & 0.470 & 0.455 \\
\hline $\operatorname{LSD}_{0.05}$ & 0.336 & 0.229 & 0.467 & 0.053 & 0.053 & 0.074 \\
\hline $\mathrm{LSD}_{0.01}$ & 0.453 & 0.309 & 0.629 & 0.071 & 0.071 & 0.100 \\
\hline Level of significance & $* *$ & $* *$ & $* *$ & NS & NS & NS \\
\hline
\end{tabular}

* and ** indicate $5 \%$ and $1 \%$ level of significance, NS: No significance, V1: Roma VF, V2: Sofol, T1: Control, T2: Fruits stored at 10 ${ }^{\circ} \mathrm{C}$ temperature, T3: Fruits stored at $15^{\circ} \mathrm{C}$ temperature, T4: Hot water treatment $\left(55^{\circ} \mathrm{C}\right)$ for $4 \mathrm{~min}, \mathrm{~T} 5$ : tomato stored in earthen cooling pot, T6: Fruits stored in food grade plastic film, T7: Fruits stored in unperforated plastic bags, T8: Fruits stored in perforated plastic bags 


\section{Disease incidence and severity}

Variation in respect of percent disease incidence was found highly significant between the varieties. It was observed that disease incidence increased with the advancement of the storage period between the varieties. However, the level of disease incidence was higher in Roma VF than Sofol. The lower (18.06\%) and the higher (21.87\%) disease incidences were recorded in Sofol at the 6th and 16th day of storage but in the case of Roma VF those values were $25.00 \%$ and $43.75 \%$, respectively presented in Fig. 3.

Variation in respect of disease severity was found to be highly significant between the varieties at all days of storage. A high disease severity level (24\%) was observed in a variety of Roma VF and it was lower $(0.36 \%)$ and was observed in variety Sofol. The combined effects of variety and post-harvest treatments showed a highly significant variation in terms of disease severity. On the 16th day of storage, the lowest $(0.33 \%)$ disease severity was in Sofol with $10{ }^{\circ} \mathrm{C}$ treatment combination and the highest (57\%) disease severity was in Roma VF with earthen pot combination (Table 10).

\section{Effect of diseases and pathogens from infected tomato fruits}

Fusarium species is one of the common pathogens of post-harvest disease-causing rot on tomato. Fusarium can appear as saprophytes pathogens on plants. Harvested tomatoes are susceptible to infections caused by Fusarium due to its succulent epicarp which enables the fungal hyphae to penetrate deeply into the fruit. The disease symptoms include rots and softening of pulp which extends into the center of the fruit. The rotted tissue is often water-soaked and becomes covered by white, yellow, or pinkish mycelia externally while the infected tissue is discolored and appears pale brown presented in Fig. 4a.

\section{Characteristics of Fusarium sp.}

Fusarium typically produce both macro and micro conidia from slender phialides. Macro conidia are hyaline, two to several celled, often moderately curved, rather wide and thick walled, and may have a slightly blunted apical end and pedicellate basal cell. Micro conidia are one- to two-celled, hyaline, pyriform, fusiform to ovoid, straight, or curved. In the present study, most of the spores were two-celled micro conidia (Fig. 4b)

\section{Shelf life}

Shelf life is an important issue for tomato, and it varies from variety to variety. The longer shelf life was observed in Sofol (17.22 days) than in Roma VF (15.04 days) (Fig. 5a). The shelf life of tomato fruits was extended following $10{ }^{\circ} \mathrm{C}, 15{ }^{\circ} \mathrm{C}$, hot water treatment, earthen cooling pot, plastic film wrap, unperforated LDPE bag, and perforated LDPE bags over control tomato, respectively (Fig. 5b).

\section{Discussion}

Effect of varieties on shelf life and quality of tomato

A significant variation was obtained among the varieties in relation to shelf life extension of tomatoes. The longer shelf life was found in Sofol variety (17.22 days) than in Roma VF (15.04 days). The shortest shelf life of Roma VF was possibly due to the highest rate of disease incidence and disease severity. The Roma VF performed better than Sofol in both cases of color and firmness. It changes due to the chlorophyll degradation or qualitative and quantitative alternations of the green pigments

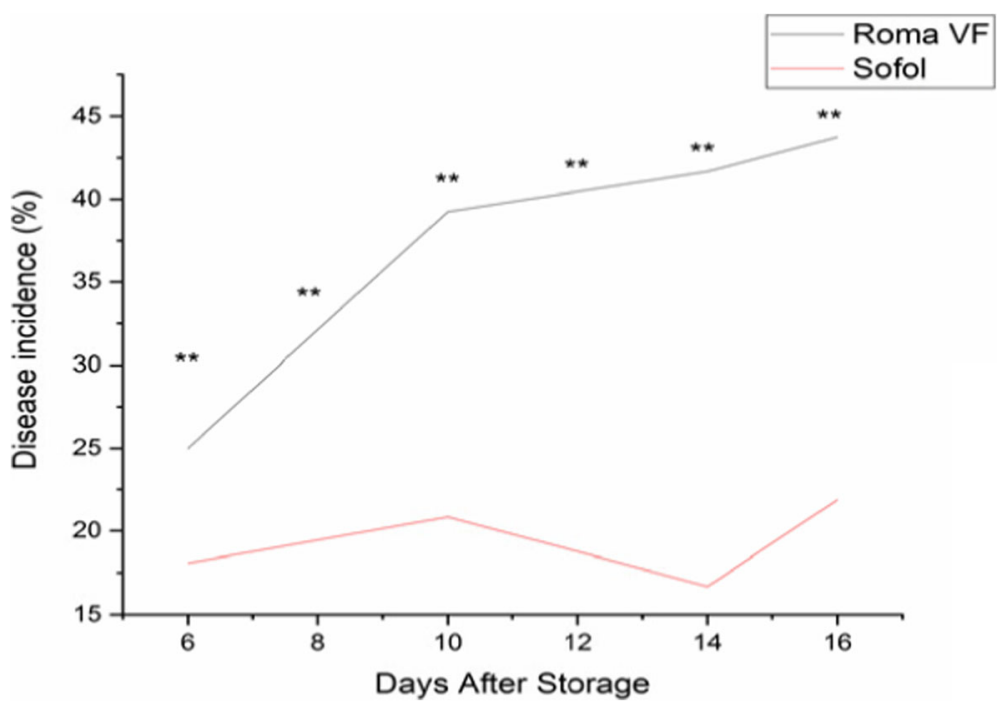

Fig. 3 Effect of variety on disease incidence of tomato during storage and ripening 
Table 10 Analysis of variance (mean square) of the data for disease incidence

\begin{tabular}{|c|c|c|c|c|c|}
\hline \multirow[t]{2}{*}{ Source of vitiation } & \multirow[t]{2}{*}{$d f$} & \multicolumn{4}{|c|}{ Disease incidence (\%) at different days after storage } \\
\hline & & 6 & 10 & 14 & 16 \\
\hline Treatment & 15 & $552.15^{* *}$ & $1443.34^{* *}$ & $1916.73^{* *}$ & $1930.02^{* *}$ \\
\hline Variety (A) & 1 & $833.583^{* *}$ & $4200.208^{* *}$ & $7501.500^{* *}$ & $5743.500^{* *}$ \\
\hline Postharvest treatment (B) & 7 & $974.866^{* *}$ & $2173.759^{* *}$ & $2648.726^{* *}$ & $2989.735^{* *}$ \\
\hline$A \times B$ & 7 & $89.226^{* *}$ & $319.089^{* *}$ & $386.917^{* *}$ & $325.524^{* *}$ \\
\hline Error & 32 & 0.537 & 0.841 & 1.818 & 1.159 \\
\hline
\end{tabular}

**Significant at $1 \%$ level of probability

into other pigments as reported by Salvador et al. (2007). The moisture content was found comparatively higher in Sofol than Roma VF. Higher losses of moisture content in the variety Roma VF could be due to their poor resistance mechanism. Although the percentage of weight loss is increased at storage, but the percentage of dry matter content is increased because fruit losses more moisture.

In this study, storage at $10^{\circ} \mathrm{C}$ temperature and modified atmosphere packaging without perforations (unperforated LDPE bags) reduced the rate of color change and the highest rate (6.13) of peel color formation was found in control treatment. At the 16th day of storage, unperforated LDPE bags (4.17) and $10{ }^{\circ} \mathrm{C}$ temperature (4.88) stored fruits were pink followed by the plastic film (5.75), earthen pot (5.85), during the storage period the color of tomato changes from the breaker to red (Table 3). Unperforated LDPE packaging and low-temperature storage showed a slower rate of firmness change of tomato during ripening and storage. At the 16th day of storage, control showed the highest rate of firmness (5.10) and modified atmosphere packaging without perforation showed the lowest rate (3.29) of firmness (Table 4). Among the treatments, unperforated LDPE and plastic film wrapping were the best in terms of controlling weight loss similar to Pesis et al. (1992). Most of the wrapping papers or bags significantly reduced the percentage of physiological weight loss in the fruits noticed by Sing et al. (2001). So, it can be concluded that the weight loss of tomato during ripening may be attributed to loss by respiration and loss of water through various mechanisms.
Moreover, the decrease in moisture content during storage was also reported by Pathmanaban et al. (1995). The highest disease incidence was found in earthen pot (70.84\%) whereas the lowest (8.33 and $12.50 \%)$ disease incidence was observed at $10{ }^{\circ} \mathrm{C}$ and $15{ }^{\circ} \mathrm{C}$, respectively, after 16th day of storage (Table 9). Feng et al. (1991) observed that controlled or modified atmosphere storage controlled post-harvest diseases. So, it can be concluded that the disease severity of treated fruits was generally lower than untreated fruits.

The shelf life of tomato fruits ranges from 10.25 to 22 days. The fruits covered with perforated plastic bag showed extended shelf life by 7 days over control, which was similar to the result observed by Yantarasri et al. (1994) and Alves et al. (1998). The increase in shelf life was probably due to the reduction of various gaseous $\left(\mathrm{O}_{2}\right.$ and $\mathrm{CO}_{2}$ ) exchange from the inner and outer atmosphere. The shortest and longest shelf lives were observed in control $\left(T_{1}\right)$ and unperforated LDPE bags $\left(T_{7}\right)$ containing fruits, respectively. In conclusion, the fruit storage at low temperatures like 10 or $15{ }^{\circ} \mathrm{C}$ temperature was good.

\section{Combined effects of varieties and post-harvest treatment} The $V_{2} T_{7}$ (Sofol with unperforated LDPE bags) combination showed slower changes in color than all other combinations. Both varieties (Roma VF and Sofol) under hot water treatment showed highest (9.16 and 12.28\%) weight loss, and the lowest (3.84 and 3.75\%) weight loss was found under unperforated LDPE bags at 14th day of storage. The minimum weight losses in unperforated

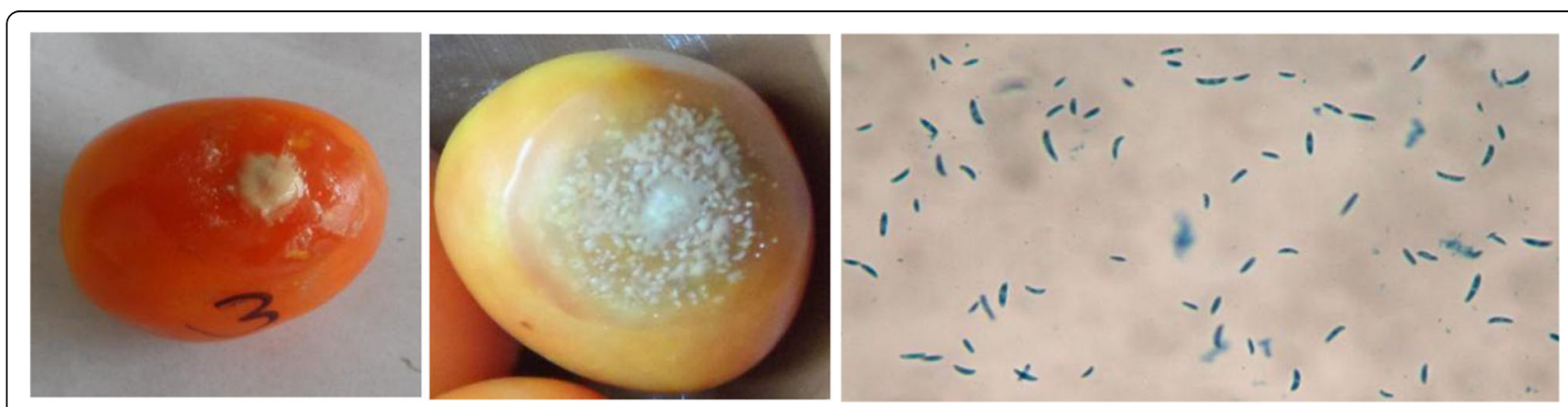

Fig. 4 Photographs showing disease (a) symptom of Fusarium rot and (b) micro conidia of Fusarium sp. 

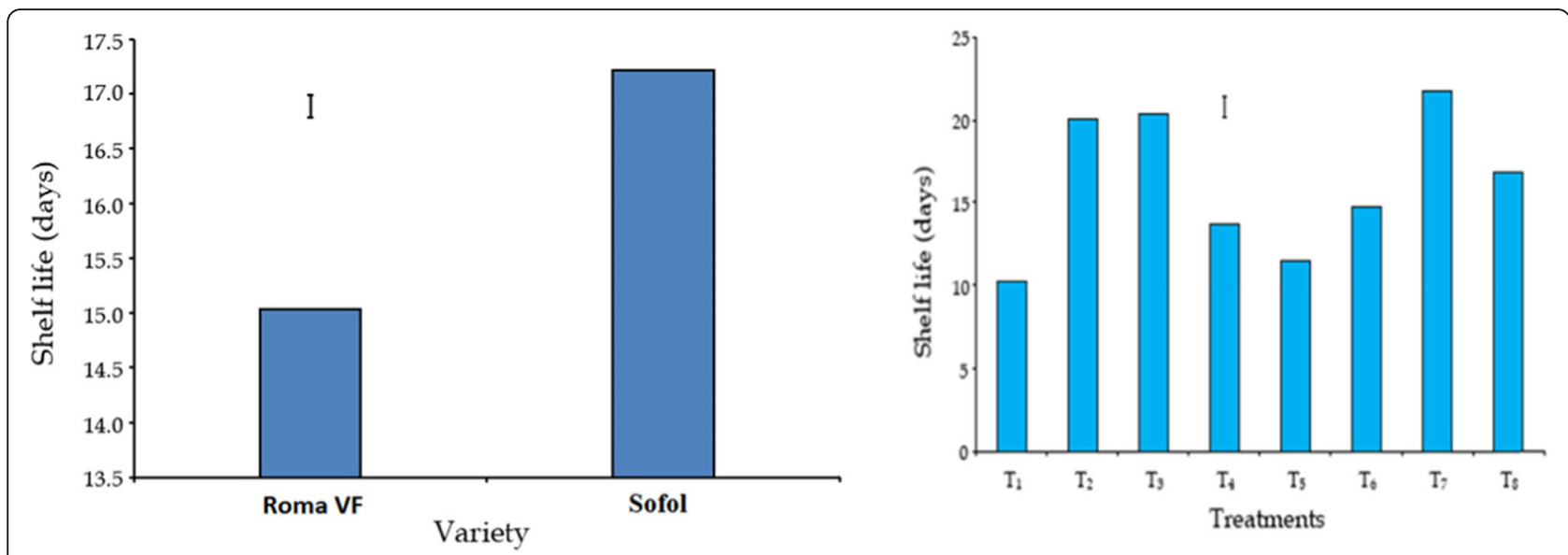

Fig. 5 a Main effects of variety on the shelf life of tomato during storage and ripening, vertical bar indicates LSD value at the $1 \%$ level of significance. $\left(V_{1}\right.$ Roma $V F, V_{2}$ Sofol) b Main effect of post-harvest treatments on the shelf life of tomato. Vertical bar indicates LSD value at the $1 \%$ level of significance

plastic bag wrapping of fruits obtained in the present study is supported by Tefera et al. (2007) and Martinez et al. (1997).

The moisture content of fruit was significantly affected by both variety and post-harvest treatments. At 4th day of storage, the higher moisture content (92.67 and 92.46\%) were found in Sofol with unperforated LDPE packaging and plastic films wrapping respectively and lower moisture content (87.80\%) was found in Roma VF with control and $10{ }^{\circ} \mathrm{C}$ temperature treatment. The increase in dry matter content with the advancement of storage period may be attributed to the corresponding decrease in moisture content due to osmotic withdrawal of water from pulp to peel by transpiration and evaporation. The maximum value of TSS $(5.73 \%$ Brix) was observed at the 12th day of storage in unperforated LDPE sealed fruits cv. Roma VF and where the minimum value of TSS (4.33\%Brix) was observed in hot water treatment in Sofol. The highest disease severity was recorded in Roma VF held at earthen pot and the lower disease severity was observed in Sofol with low-temperature storage at $10{ }^{\circ} \mathrm{C}$.

At 12th day of storage, the highest pulp pH (4.83) observed in cv. Roma VF sealed with plastic film whereas, Sofol sealed with unperforated LDPE bag shown lowest pulp $\mathrm{pH}$ (4.47) in the same days of storage. The combined effects of variety and different post-harvest treatments in respect of titratable acidity were statistically not significant at different days of storage. Maximum vitamin $C$ was lost when the fruits were stored at room temperature $\left(28.2-31.1{ }^{\circ} \mathrm{C}\right)$. The highest vitamin $\mathrm{C}$ content 18.08 and $18.05 \mathrm{mg} / 100 \mathrm{~g}$ was recorded in Sofol with unperforated LDPE bags combination and the lowest 11.40 and $10.48 \mathrm{mg} / 100 \mathrm{~g}$ was recorded in Roma VF with control combination at the 8th and 12th days of storage, respectively. The longest shelf life (24 days) was observed in tomato fruits of variety Sofol when held in unperforated LDPE bags followed by $10{ }^{\circ} \mathrm{C}$ (22 days) and $15{ }^{\circ} \mathrm{C}$ (22 days). The shelf life of tomato at 10 and $15^{\circ} \mathrm{C}$ were statistically identical. The modified atmosphere storage of tomato using LDPE bag enhanced shelf life, which was probably due to the reduction of the exchange of various gases $\left(\mathrm{O}_{2}, \mathrm{CO}_{2}\right)$ from inner and outer atmosphere as well as slowing down the process leading to ripening by different post-harvest treatments.

\section{Conclusions}

This study was found that the post-harvest treatments caused a significant effect on color, firmness, weight loss, moisture content, dry matter content, chilling injury, total soluble solids, $\mathrm{pH}$, titratable acidity, vitamin $\mathrm{C}$ content, disease incidence, disease severity, and shelf life. The unperforated plastic bag was discovered to be the best among all post-harvest treatments to reduce weight loss, disease incidence, and severity of disease, and extend tomato shelf life. Therefore, it can be concluded that the results of this experiment will be useful with particular reference to long- and medium-term storage, quality control, transportation and marketing, growers, and consumers. Moreover, further studies are suggested to examine the effects of other promising varieties and post-harvest treatments on shelf life, quality and safety of tomato in the agricultural supply chain in Bangladesh.

\section{Abbreviations \\ LDPE: Low-density polyethylene; TA: Titratable acidity; TSS: Total soluble solids}

\section{Acknowledgements}

The authors are very grateful to Professor Dr. Md. Kamrul Hassan and Professor Dr. M. F. Mondal of the Bangladesh Agricultural University for his technical support and helpful for his comments and discussion and also 
thanks to the Department of Plant Pathology and Biochemistry and Molecular Biology for identifying post-harvest diseases and causal pathogens and chemical analysis of the experimental samples.

\section{Authors' contributions}

SRS contributed to the conceptualization, data curation, and writing —original draft preparation. MASJ, MAR, MAA, MAK contributed to the writing, review, and editing of the manuscript. AS supervised the study. AS and MF contributed to data analysis and visualization. All authors revised, read, and approved the final manuscript.

\section{Funding}

There are currently no funding sources in the design of the study and collection, analysis, and interpretation of data and in writing the manuscript.

\section{Availability of data and materials}

The datasets generated and/or analyzed during the current study are included in this study.

\section{Ethics approval and consent to participate}

Not applicable.

\section{Consent for publication}

Not applicable.

\section{Competing interests}

The authors declare that they have no competing interests.

\section{Author details}

'Department of Horticulture, Bangladesh Agricultural University, Mymensingh, Bangladesh. ${ }^{2}$ Institute of Environmental and Sustainable development in Agriculture, Chinese Academy of Agricultural Science, Beijing 100081, China. ${ }^{3}$ Department of Crop Genetics and Breeding, Institute of Crop Sciences, Chinese Academy of Agricultural Sciences, Beijing 100081, China. ${ }^{4}$ Institute of Agricultural Resources and Regional Planning, Chinese Academy of Agricultural Science (CAAS), Beijing, China. ${ }^{5}$ Rural Development Academy, Bogura 5842, Bangladesh.

Received: 5 August 2019 Accepted: 14 November 2019

Published online: 11 December 2019

\section{References}

Ahmed K U (1976) "Phul Phal O Shak Shabji (in Bangla)". 2nd Edition, Alhaj Kamaluddin Ahmed, Banglow No. 2, Farm Gate, Dhaka, Bangladesh. 470. Ali SY, Ahiduzzaman SA, Abdul MB, Nafis I, Jakaria CO, Rahman H (2015)

Comparative effects on storage period of varieties Pineapple fruits. Res Agric Livest Fish. 2(3):395-410

Alves RMV, Sigrist JMM, Paduia M (1998) Tommy Atkins mangoes under modified atmosphere. Revista Brasileira de Fruticultura. 20(2):220-228

Arah IK, Ernest KK, Etornam KA, Harrison A (2015) An overview of post-harvest losses in tomato production in Africa: causes and possible prevention strategies. J Biol Agric Healthcare. 5(16):78-88

BBS. Monthly Statistical Bulletin (2012) Statistics division, ministry of planning. Government of the People's Republic of Bangladesh, p 305

Chowdhury B (1979) Vegetables, 6th edn. The Director, National Book trust, New Delhi, p 46

Coursey DG (1971) Tomato. In: Post harvest biotechnology of vegetables. CRC Press, Incorporation, Boca Raton, p 60

Feng SQ, Chen XY, Wu HZ, Zhou ST (1991) The methods of delaying ripening and controlling postharvest diseases of mango. Acta Horticulturae. 17(4):61-65

Firmin A (1997) Physico-chemical changes in papaya during storage. Trop Sci. 37(1):49-51

Gomez KA, Gomez AA (1984) Statistical Procedure for Agricultural Research (2nd Edition). Willey, New York, pp 28-92

Hassan MK, Chowdhury BLD, Akhther N (2010) Final report of USAID and EO funded project (jointly implemented by FAO and FPMO of MoFDM) entitled "Post-Harvest Loss Assessment: A Study to Formulate Policy for Loss Reduction of Fruits and Vegetables and Socioeconomic Uplift of the Stakeholders". 189.

Kalloo D, Sachdev RN (1985) Tomato. Allied Publishers Pvt. Ltd, India, p 33
Lashley D (1984) Advances in postharvest technology and new technologies in food production. Proceedings of Seminar in St. Augustine, Trinidad Tobago, pp 173-183

Martinez BE, Guevara GC, Contreras MJ, Rodgiguez R (1997) Preservation of mango Azucar variety (Mangifera indica L.) at different storage stages. Acta Horticulturae. 455:747-754

Patel RB, Patel GS (1991) Post harvest diseases of the tomato (Lycopersicon esculentum) fruits and their control. Ind J Agric Res. 25(4):173-176

Pathmanaban G, Nagarajan M, Manian K, Annamalainathan K (1995) Effect of fused calcium salts on postharvest preservation in fruits. Madras Agric J 82:47-50

Pesis E, Marinansky R, Subhadrabandhu S (1992) Influence of fruit coating on papaya quality. Acta Horticulturae. 321:659-666

Ranganna S (1979) Titralable acidity. In: Manual of analysis of fruit and vegetable products. (Ranganna, S., FAl.). Tata McGraw Hill Publ. Co. Ltd, New Delhi, pp 7-8

Salvador A, Sanz T, Fiszman SM (2007) Changes in colour and texture and their relationship with eating quality during storage of two different dessert bananas. Postharvest Biol Technol 43:319-325

Sing Z, Janes J, Suresh N, Sing Z, Ben AR, Hadas SP (2001) Packaging materials affect physiological weight loss fruit colour and quality of mango during storage. Acta Horticulturae. 2:603-604

Tefera A, Seyoum T, Woldetsadik K (2007) Effect of disinfection, packaging, and storage environment on the shelf life of mango. Department of Food Science and Postharvest Technology, College of Agriculture, Haramaya University, Haramaya. 96(2):201-212.

Wills RBH, McGllasson WB, Grahmam D, Lee TH, Hall EG (2004) Postharvest; An Introduction to the Physiology and Handling of Fruits and Vegetables. Granada Publishing Ltd, London, p 24

Yantarasri T, Ben YS, Rodov V, Kumpuan W, Uthaibutra J, Sornsrivichai J (1994) Development of Perforated modified atmosphere package for mango. Acta Horticulturae. 398:81-91

Zhang XY, Yu XX, Yu Z, Xue YF, Qi LP (2014) A simple method based on laboratory inoculum and field inoculum for evaluating potato resistance to black scurf caused by Rhizoctonia solani. Breed Sci. 64:156-163

\section{Publisher's Note}

Springer Nature remains neutral with regard to jurisdictional claims in published maps and institutional affiliations.

\section{Submit your manuscript to a SpringerOpen ${ }^{\circ}$ journal and benefit from:}

- Convenient online submission

- Rigorous peer review

- Open access: articles freely available online

High visibility within the field

- Retaining the copyright to your article

Submit your next manuscript at $\boldsymbol{\nabla}$ springeropen.com 